\title{
Exploring Competitive Advantage through Lean Implementation in the Aerospace Supply Chain
}

\author{
Valerie Crute, Allan Wickham, Richard Johns and Andrew Graves \\ UK Lean Aerospace Initiative, School of Management \\ University of Bath, Bath, United Kingdom
}

\begin{abstract}
This research paper provides an initial exploration of the factors influencing whether lower tier suppliers gain a competitive advantage through their implementation of Lean manufacturing, and highlights the implications for the aerospace industry and for the SMEs. The research findings indicated that the SMEs regarded Lean as a necessity to meet the growing demands of their customers and to remain profitable in an increasingly competitive environment. The study concludes that while Lean initiatives have lead to numerous benefits for the SMEs, the assumption can not be made that Lean initiatives directly provide sustainable competitive advantage, as this is dependent on a number of complex and interdependent issues.
\end{abstract}

\section{Introduction}

Many UK aerospace companies are in the process of adopting the lean manufacturing philosophy, developed in the automotive industry by Toyota $(1,2)$. As Lee and Oakes (3) suggest, at the forefront of Lean implementation are the prime aerospace manufacturers whose increasing dependence on outsourcing places significant pressure on the smaller component manufacturers to undergo significant change. Lee and Oakes state, "[as] large companies concentrate on their core activities, the development of alliances and partnerships becomes a key strategic issue and smaller firms struggle to compete on cost, quality and delivery, to maintain a place within a supply chain" (p.197). Many lower-tier suppliers are now attempting to implement Lean practices in their operations (4). Suppliers recognise that they must either develop the capabilities that customers seek or face the possibilities of acquisition or exit from the industry, through diversification or closure. For many SMEs Lean implementation has become 'a survival issue as well as an improvement issue' (4). However, while Lean implementation has been shown to provide operational benefits, it is difficult to track the financial benefits associated

Please use the following format when citing this chapter:

Crute, V., Wickham, A., Johns, R. and Graves, A., 2008, in IFIP International Federation for Information Processing, Volume 257, Lean Business Systems and Beyond, Tomasz Koch, ed.; (Boston: Springer), pp. 357-364. 
with these improvements (5) and to identify whether such benefits have provided competitive advantage.

The term 'strategic competitive advantage' emerged in 1985, when Porter identified types of strategies the firm can implement to gain competitive advantage. He went on to describe that when these advantages are resistant to erosion by competitors' efforts then firms achieve sustainable competitive advantage (6). This concept of sustained competitive advantage was then further defined by Barney (7), " a firm is said to have a sustained competitive advantage when it is implementing a value creating strategy not simultaneously being implemented by any current or potential competitors and when these other firms are unable to duplicate the benefits of this strategy" (p102). Barney $(7,8)$ argues that the sustainability of competitive advantage depends upon the possibility of duplication by current or future competitors, that is competitive advantage is only sustained if it continues to exist after all the efforts to duplicate the advantage have ceased.

However, creating more value than your competitors is not enough unless this difference is recognised by the customer within the marketplace. Coyne (9) reflected this when he stated that "For a producer to enjoy competitive advantage in a product/market segment, the difference or differences between him and his competitors must be felt in the marketplace: that is they must be reflected in some product or delivery attribute that is a key buying criterion for the market" (p.55). Inherent in this definition is the idea that the customer ultimately defines the value of the product.

Collis and Montgomery (10) noted that the Lean manufacturing principles of Japanese automobile companies were based on organisational resources embedded in the culture, routines, and processes of a company and as such, they considered Lean to be a source of competitive advantage. However, this may not be the case for SMEs and little attention has been directed to the question "Does Lean implementation give small aerospace suppliers sustainable competitive advantage?"

\section{Methodology:}

This research paper provides an initial exploration of the factors influencing whether lower tier suppliers gain a competitive advantage through their implementation of Lean manufacturing, and highlights the implications for the aerospace industry and for the SMEs. The exploratory case study method was chosen due to the lack of current research in the area (11).

A "purposive" or "judgemental" sampling method $(11,12)$ was used to identify cases where lean practices had been implemented, operational benefits had been gained and the research could examine the companies' perspective on competitive advantage. Qualitative semi-structured interviews were completed within three Small Medium Enterprises resulting in an exploratory multi-case study. A number of procedures carried out during data collection ensured the reliability of the findings including the production of an interview protocol ensured repeatability of the research (11). In each of the case studies interviews were completed with the General Manager, Production Manager and Production Engineer or Cell Leader. The 
interviews focused on the motivation for Lean implementation; identifying any benefits gained; and the companies' assessment of competive advantage gained through Lean implementation.

The three companies involved in the study were:

- Company A - a supplier of highly technical insulations to the aerospace industry, engineering lightweight high temperature thermal insulation systems for various applications.

- Company B - produces high quality and well-priced products to service the aerospace industry, providing expert solutions to machining requirements.

- Company $\mathrm{C}$ - a modern machine shop producing high precision components and assemblies to the aerospace industry. The company has both manufacturing and engineering capabilities.

This qualitative method is powerful in that it is often used to generate hypotheses and to identify variables to use in quantitative approaches (13). Future studies can subsequently use a quantitative or positivistic method to test the hypotheses that the exploratory multi-case study proposes.

\section{Findings and discussion:}

\subsection{Motivation for implementing Lean}

The primary motivation for implementing Lean initiatives amongst all the companies interviewed was to gain improvements in Quality, Cost, and Delivery metrics, and the SMEs interviewed regarded Lean as a necessity to meet the growing demands of their customers and to remain profitable in an increasingly competitive environment. Interestingly, all the SMEs interviewed had decided to undergo Lean improvements as part of their own initiative without any coercion or external pressures from customers. There was no assistance or collaborative participation from customers. This suggests that the Lean initiatives undertaken in each company were appropriate to the strategic intent of the business rather than a tactical response to customer demands. It was also clear from the interviews that none of the companies had explicitly linked Lean implementation with gaining competitive advantage and gaining competitive advantage was not a motivating factor for any of the companies at the start of their implementation process.

Hamel and Prahalad (14) favour a strategic approach to change. They highlight that business change is inevitable and that the real issue is whether this change will happen in a crisis atmosphere or with consideration and foresight. They advocate change that is made not to mimic competitors but to fit opportunities in the future environment. In this respect, Lean implementation within SMEs within this study was an appropriate strategy for dealing with the change of competitive environment within the aerospace industry. 


\subsection{Benefits of Lean implementation}

The companies reported the following tangible benefits of Lean implementation to their organizations (Table 1).

Table 1. Reported tangible benefits of Lean implementation to the organisation

\begin{tabular}{|l|l|l|l|}
\hline $\begin{array}{l}\text { Tangible } \\
\text { Benefits }\end{array}$ & Company A & Company B & Company C \\
\hline Financial & Increased profitability & $\begin{array}{l}\text { Decreased stockholdings. } \\
\text { Improved cash flow. } \\
\text { Increased profitability. }\end{array}$ & Increased profitability \\
\hline Operational & $\begin{array}{l}\text { M3\% reduction in } \\
\text { focus part } \\
\text { manufacturing time. } \\
\text { Less effort finding } \\
\text { equipment. } \\
\text { Improved scheduling } \\
\text { of work. }\end{array}$ & Monitor progress of orders. & $\begin{array}{l}\text { Increased people } \\
\text { productivity. } \\
\text { Reduced set-up times. } \\
\text { Production up from } \\
60,000 \text { to 140, 000 } \\
\text { parts per month. }\end{array}$ \\
\hline
\end{tabular}

The research identified similar benefits from Lean implementation to other organisations within the supply chain including reduced manufacturing times, and reduced changeover times. However as Slack et al., (15) point out, the firm must understand what factors of performance the customer values and strive to satisfy them. They highlight that the performance objectives of the firm's operations are dependent upon the competitive factors that define the customer's requirements. The companies in this study identified cost and delivery performance as being of particular importance to their customers and linked the benefits of lean implementation to the achievement of their quality, cost and delivery (QCD) performance objectives in the following way (Table 2):

Table 2. Reported contribution of Lean activities to QCD Performance Objectives

\begin{tabular}{|l|l|l|l|}
\hline $\begin{array}{l}\text { Performance } \\
\text { Objectives }\end{array}$ & Company A & Company B & Company C \\
\hline Quality & Operational efficiency \\
allows price reductions. & $\begin{array}{l}\text { The system highlights } \\
\text { areas to improve. }\end{array}$ & $\begin{array}{l}\text { Higher throughput } \\
\text { reduces costs. }\end{array}$ & $\begin{array}{l}\text { Price reductions in face } \\
\text { of increasing material } \\
\text { and labour costs. }\end{array}$ \\
\hline Delivery Performance & $\begin{array}{l}\text { Delivery expectations } \\
\text { exceeded due to } \\
\text { reduction in } \\
\text { manufacturing times. }\end{array}$ & $\begin{array}{l}\text { Visibility has } \\
\text { improved scheduling, } \\
\text { improving reliability } \\
\text { of supply. }\end{array}$ & $\begin{array}{l}\text { Improvements in on- } \\
\text { time delivery, from } \\
15 \% \text { to approximately } \\
85 \% .\end{array}$ \\
\hline
\end{tabular}

The companies also reported less tangible benefits including improved training of staff, clearer communication of business objectives, knowledge transfer, improved morale and a perceived culture change to embrace continuous improvement. Collis and Montgomery (10) consider cultural change to be the most significant of these factors, facilitating the competitive revitalisation and the 
future competitiveness of the firm and the findings in this study echo findings in the automotive sector.

\section{Competitive advantage through Lean implementation}

While it was possible to identify operational and cultural benefits, a more complex picture emerged on whether these benefits lead to competitive advantage. It is clear from the results that Lean had created capability gaps among competitors. For example, Company A in particular saw that the implementation of Lean had improved the company image and helped with networking. These improvements may enhance the company's capability to brand their products or services. Urde (16) recognised that competency at creating a brand image can be a source of competitive advantage. Lean also enables the firms to exceed the delivery expectations of customers leading to customer satisfaction. Good service, leading to customer satisfaction is a core competence that leads to competitive advantage $(17,18)$.

Evidence from the interviews suggests that Lean affects the culture of the firm. Collis and Montgomery (10) saw that the Lean manufacturing principles of Japanese automobile companies were based on organisational resources embedded in the culture, routines, and processes of a company and as such, they saw Lean as a source of competitive advantage. The interviewed firms described Lean as creating a learning curve, suggesting that competitors may always be behind the improvements of the first movers. In addition, the companies interviewed had implemented Lean in a quiet period in the industry, and firms implementing Lean in the future may find it more difficult due to an increasing conflict between running their day-to-day operations and making continuous improvements.

Hamel and Prahalad (14) recognised that to remain competitive for the future, companies need to continually adapt. Lean and its philosophy of continuous improvement would be one way to achieve the continual development and flexibility of core competencies required by the firm. Prahalad and Hamel (19) propose that an organisation's capacity to improve existing skills and learn new ones is the most defensible competitive advantage of all. Therefore, continuous improvement is a dynamic capability, which provides the basis for achieving and sustaining a competitive edge in an uncertain and rapidly changing environment (20).

All of the companies interviewed highlighted that maintaining the advantage of path dependency is dependent upon the other resources of the company. The Toyota Production System philosophy or the Toyota DNA is described by Drickhamer (21) as "a tight coupling of doing work and learning to do work better" (p. 26). The Lean approach does require a long-term commitment that is difficult for many organisations to maintain, especially with constantly rotating managerial ranks (21). Therefore, the sustainability of Lean as a source of competitiveness requires that the firm's make available adequate resources to maintain the momentum of its continuous improvement programmes.

Several of the interviewees highlighted that the benefits of Lean did not necessarily lead to competitive advantage. Interview responses suggested that the benefits of Lean only lead to increased competitiveness if they were perceived as 
favourable attributes by the customer, that is if they contribute to customer value and therefore customer satisfaction. Coyne (9) also refers to this link between business advantage and competitive advantage. For example, he argues that having lower costs will result in significantly higher margins, but describes that this business advantage only leads to competitive advantage if the producer recycles the additional profits into delivery attributes or product attributes that will be valued within the marketplace. Therefore, the benefits of Lean only lead to increased competitiveness if they are perceived as favourable attributes by the customer, that is if they contribute to customer value and therefore customer satisfaction. As in previous research (4), there was suspicion among the SMEs that some customers used Lean initiatives to reduce their suppliers operating margins, rather than to reduce waste from across the value stream. Several interviewees suggested that their customers lacked the required understanding of Lean, or were more concerned with forcing cost reductions. In addition, some customers encouraged suppliers to hold stock for them. Johns, Crute, and Graves (4) regard this as having a negative affect upon the supplier's profitability and therefore the practice is not conducive to Lean thinking. The poor practices of the customers may be due to the behavioural legacies rooted in mass production, which affect efforts to rapidly introduce change into the aerospace supply chain (22). Traditionally, there has been little inter-firm collaboration in Western business models and Lean conflicts with many preconceptions such as economies of scale. It is the attitudes of some customer organisations that may therefore prevent Lean from becoming a source of competitive advantage for some SMEs.

There was also some evidence in this study that respondents saw the Lean implementation as an 'order-qualifier' rather than 'order-winner'. Hill (23) describes order-winning factors as those things that directly and significantly contribute to winning business; they are the customer's key buying criteria. They are an important determinant of a competitor's stance, as rising performance in one of these areas will either result in more business or improve the chances of gaining new business (15). These factors therefore contribute to competitive advantage, enabling the firm to sustain profits above those of their rivals. Qualifying factors are the threshold requirements of any aspect that are necessary just for the organisation to be considered by the customer, and to therefore remain in business within the industry (Hill, 23). Any improvement upon the threshold level of a qualifying factor will not win the company further business and therefore will not gain competitive benefit (15). Some interviewees expressed the concern that Lean is becoming increasingly seen as an order-qualifier and therefore a pre-requisite for entry into the industry rather than order winner.

\section{Conclusions}

This study suggests that the SMEs considered Lean initiatives as an appropriate strategy for dealing with changes of the competitive environment in the aerospace industry, rather than as a tactical response to customer demands. It was also apparent that Lean gives SMEs similar benefits to other organisations within the supply chain. 
Benefits included improvements in cash flow and profitability, reduced manufacturing times, reduced changeover times, improved training of staff, communication of business objectives, knowledge transfer and improved morale. Although it is clear that these benefits give business advantage in terms of improvements in QCD, it is harder to determine whether these business advantages lead to competitive advantage.

The study concludes that while Lean initiatives have lead to numerous benefits for the SMEs, the assumption can not be made that Lean initiatives directly provide sustainable competitive advantage, as this is dependent on a number of complex and interdependent issues. Further research will clearly be needed to assess the extent to which these results can be generalised to other SMEs in the sector. Likewise future areas for research are suggested which can further clarify the relationship between operational improvement and competitive advantage.

\section{References}

1. Womack J.P, Jones D.T, Roos, D. The Machine that Changed the World. New York: Rawson Associates (1990).

2. Womack, J. P. and Jones, D. T. Lean Thinking: Banish waste and create wealth in your organisation. Simon and Schuster: New York (1996).

3. Lee, G. L., and Oakes, I. K. "Templates for change with supply chain rationalisation." International Journal of Operations and Production Management. 16(2): 197-209 (1996).

4. Johns, R., Crute, V. and Graves, A. "Lean Supply: Cost Reduction or Waste Reduction?" The Society of British Aerospace Companies, October (2002).

5. Standard, C. and Davis, D. "Lean thinking for Competitive advantage" SAE International [online] (2000). Available from http://www.sae.org/topics/Leandec00 .htm [accessed 11/06/2006].

6. Porter, M. E. 1985. Competitive Advantage: Creating and Sustaining Superior Performance. The Free Press: New York (1985).

7. Barney, J. B. "Firm resources and sustained competitive advantage." Journal of Management. 17(1): 99-120 (1991).

8. Barney, J. B. Gaining and Sustaining Competitive Advantage. Addison Wesley: Harlow (1997).

9. Coyne, K. "Sustainable Competitive Advantage: What it is, what it isn't." Business Horizons 29 (January-February): 54-61 (1986). 
10. Collis, D. J., and Montgomery, C. A. "Competing on Resources: Strategy in the 1990s.” Harvard Business Review. July- August: 118-128 (1995).

11. Yin, R. K. Case Study Research Design and Methods 3rd edition (2003).

12. Saunders, M., Lewis, P., and Thornhill, A. Research Methods for Business Students. Pitman Publishing: London (1997).

13. Malhotra, N. K. and Birks, D. F. Marketing Research: An Applied Approach. Prentice Hall: Harlow, Essex (2002).

14. Hamel, G., and Prahalad, C. K. "Competing for the Future" Harvard Business Review (July-August 1994): 122-128.

15. Slack, N., Chambers, S., Harland, C., Harrison, A. and Johnston, R. Operations Management. 2nd Edition. Financial Times Prentice Hall: Harlow (1998).

16. Urde, M. "Brand Orientation: A mindset for building brands into strategic resources.” Journal of Marketing Management. 15(1-3): 117-134 (1999).

17. Katayama, H. and Bennett, D. "Lean production in a changing competitive world: a Japanese perspective." International Journal of Operations and Production Management. 16(2): 8-23 (1996).

18. Mariotti, J. "Great Service: The Ultimate Competitive Advantage." Industry Week.com (1997). [online]. Available from http://www.industryweek.com/columns /asp/ ColumnId=302 [accessed 11/02/2006].

19. Prahalad, C. and Hamel, G. "The Core Competence of the Corporation." Harvard Business Review, 68 (May-June): 79-91 (1990).

20. Bessant, J., and Francis, D. "Developing strategic continuous improvement capability." International Journal of Operations and Production Management. 19(11): 1106-1119 (1999).

21. Drickhammer, D. "Lean Manufacturing: The 3rd Generation" Industry Week March 2004: 25-30 (2004).

22. Michaels, L. M. J.. "The making of a Lean aerospace supply chain." Supply Chain Management: An international Journal. 4(3): 135-145 (1999).

23. Hill, T. Operations Management: strategic context and managerial analysis. London: MacMillan Press (1993). 